\title{
Immunohistochemical Visualization of Amyloid- $\beta$ Protein Precursor and Amyloid- $\beta$ in Extra- and Intracellular Compartments in the Human Brain
}

\author{
Leena Aho ${ }^{\mathrm{a}}$, Maria Pikkarainen ${ }^{\mathrm{a}}$, Mikko Hiltunen ${ }^{\mathrm{a}}$, Ville Leinonen ${ }^{\mathrm{b}}$ and Irina Alafuzoff ${ }^{\mathrm{a}, \mathrm{c}, *}$ \\ ${ }^{a}$ Department of Clinical Medicine, Unit of Neurology, University of Eastern Finland, Kuopio, Finland \\ ${ }^{\mathrm{b}}$ Department of Neurosurgery, Kuopio University Hospital, Kuopio, Finland

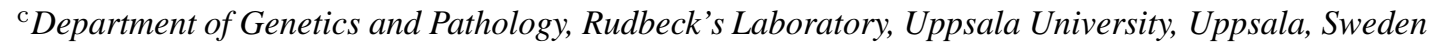

Accepted 20 January 2010

\begin{abstract}
Amyloid- $\beta$ (A $\beta$ ) peptide, a cleavage product of the amyloid- $\beta$ protein precursor $(\mathrm{A} \beta \mathrm{PP})$, has been reported to be detected in the intracellular compartment. Most studies reporting the presence of intracellular $\mathrm{A} \beta$ are based on the use of immunohistochemistry. In this study, the presence of $\mathrm{A} \beta \mathrm{PP}$ and $\mathrm{A} \beta$ was assessed by applying immunohistochemistry in postmortem human brain tissue samples obtained from 10 neurologically intact subjects, the youngest being 2 years of age, one aged with mild cognitive impairment, 14 neurologically diseased, and in one brain biopsy sample obtained from a subject with normal pressure hydrocephalus. Intracellular immunoreactivity was detected in all ages independent of the disease state or existence of extracellular $\mathrm{A} \beta$ aggregates with all antibodies directed to $\mathrm{A} \beta \mathrm{PP}$, with three $\mathrm{A} \beta$ antibodies (4G8, $6 \mathrm{E} 10$, and 82E1), clones that are unable to distinguish $\mathrm{A} \beta$ from $\mathrm{A} \beta \mathrm{PP}$. These results suggest that it is $\mathrm{A} \beta \mathrm{PP}$ rather than $\mathrm{A} \beta$ that is detected intracellularly when using the antibodies listed above. Furthermore, the staining results varied when different pretreatment strategies were applied. Interestingly intracellular $\mathrm{A} \beta$ was detected with antibodies directed to the C-terminus of $\mathrm{A} \beta$ (neoepitope) in subjects with Alzheimer's disease. The lack of intracellular immunoreactivity in unimpaired subjects, when using antibodies against neoepitopes, may be due to a lack or a low level of the protein that is thus undetectable at light microscopic level by immunohistochemistry method. The staining results and conclusions depended strongly on the chosen antibody and the pretreatment strategy and thus multiple antibodies must be used when assessing the intracellular accumulation of $\mathrm{A} \beta$.
\end{abstract}

Keywords: Amyloid- $\beta$, immunohistochemistry, intracellular, postmortem brain

\section{INTRODUCTION}

Already by the late 1980 s, intracellular amyloid- $\beta$ peptide $(\mathrm{iA} \beta)$ [1] was reported to be seen in the brains of both subjects with Alzheimer's disease (AD) and controls applying an antibody that is commonly used

*Correspondence to: Irina Alafuzoff, Department of Genetics and Pathology, Rudbeck's Laboratory, Uppsala University, Dag Hammarsköldsväg 20, SE-75815, Uppsala, Sweden. E-mail: irina. alafuzoff@genpat.uu.se. in neuropathological diagnostics (clone 4G8). A review of the literature reveals that while applying various commercial antibodies (Table 1), iA $\beta$ has been reported to be detected in cell culture, in the brains of wild and transgenic animals, in brains obtained from subjects with Down's syndrome, AD, and HIV, and in young drug abusers as well as in brains obtained from children and aged without any known neurological disorders [1-23]. It is noteworthy and disturbing that there is considerable variation in results not only while applying a different antibody but even with the 


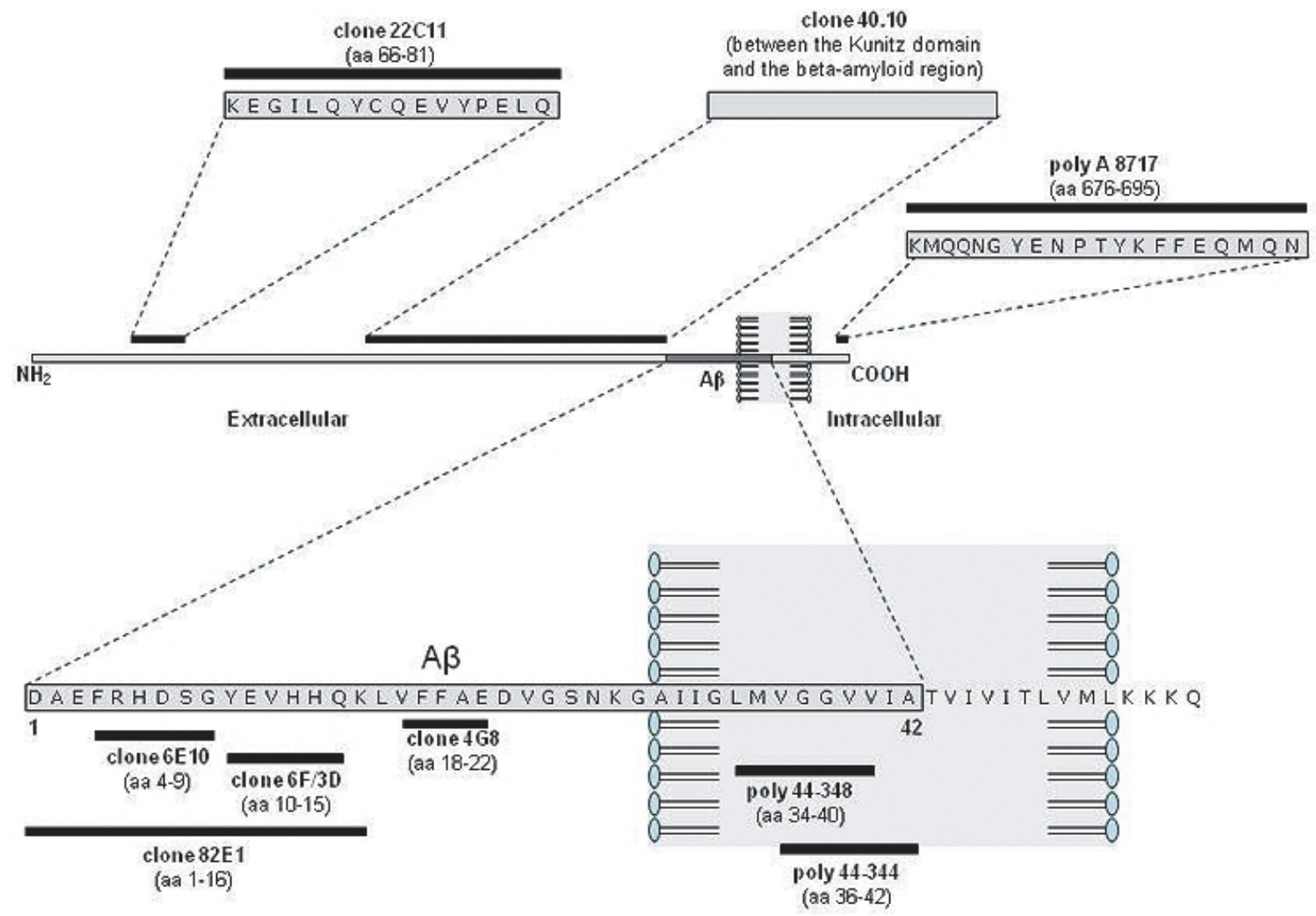

Fig. 1. A schematic presentation of the amyloid- $\beta$ protein precursor $(\mathrm{A} \beta \mathrm{PP})$ where the epitope regions recognized by the antibodies used in this study are marked with black $(\mathrm{A} \beta \mathrm{PP} / \mathrm{A} \beta)$ and gray bars $\left(\mathrm{A} \beta\right.$ neoepitopes). Clone $82 \mathrm{E} 1$ is raised against $\mathrm{A} \beta_{1-16}$ (Immuno-Biological Laboratories). Clone $6 \mathrm{E} 10$ is raised against $\mathrm{A} \beta_{1-17}$ (Signet) [3,56,57]. Clone $6 \mathrm{~F} 3 \mathrm{D}$ is raised against $\mathrm{A} \beta_{8-17}$ (DakoCytomation) [3,58]. Clone 4G8 (Signet) is raised against $\mathrm{A} \beta 17-24$ (Signet) [3,58]. Clone 12F4 is raised against $\mathrm{A} \beta_{1-42}$ (Covance) and is reactive to $\mathrm{C}$-terminus of $\mathrm{A} \beta$ and is specific for the isoform ending at the $42 \mathrm{nd}$ amino acid. Clone 22C11, is raised against recombinant Alzheimer precursor A4 fusion protein; clone 40.10, is raised against the sequence between Kunitz protease inhibitor domain and the beta-amyloid region (Novocastra). The specificity of polyclonal antibodies as provided by the manufacturer: poly 44-348 (Biosource/Invitrogen), poly 44-344 (Biosource/Invitrogen), and poly A 8717 (Sigma). A $\beta$, amyloid- $\beta$

same antibody (see Table 1).

A $\beta$ consists of 40-43 amino acids and is a cleavage product of the transmembrane amyloid- $\beta$ protein precursor ( $\mathrm{A} \beta \mathrm{PP})$, encoded as a single-copy gene on chromosome 21 [24-28]. A $\beta$ PP is widely expressed in the brain. The cleavage of $\mathrm{A} \beta \mathrm{PP}$ has been reported to occur when $\mathrm{A} \beta \mathrm{PP}$ is located at the plasma membrane, endoplasmic reticulum, endosomal and lysosomal membranes [29], trans-Golgi network [30], and mitochondrial membrane [31]. Thus, the cleavage product, $\mathrm{A} \beta$, could be expected to be found in the intracellular compartment.

Most studies reporting the presence of iA $\beta$ (Table 1) are based on the use of immunohistochemistry (IHC). In IHC, antibodies, which recognize a specific sequence of amino acids, are used, i.e., an antibody recognizes usually only small part of a longer peptide (Fig. 1).
With respect to both $\mathrm{A} \beta \mathrm{PP}$ and $\mathrm{A} \beta$, numerous commercial and in house monoclonal and polyclonal antibodies are available. As is seen in Fig. 1, some of the amino acid sequences, i.e., epitopes, are shared by $\mathrm{A} \beta$ and $\mathrm{A} \beta \mathrm{PP}$. It has been demonstrated that clone $6 \mathrm{E} 10$, which is specific for the sequence $4-13$ of human $\mathrm{A} \beta$, detects not only $\mathrm{A} \beta$ but also $\mathrm{A} \beta \mathrm{PP}[32,33]$, and clone $4 \mathrm{G} 8$, which is directed to the mid-portion of $\mathrm{A} \beta$, reacts to $\mathrm{A} \beta$ and $\mathrm{A} \beta \mathrm{PP}$ derivatives in Western blots [34]. Thus, intracellular staining with monoclonal antibodies such as $6 \mathrm{E} 10$ or $4 \mathrm{G} 8$ may be detecting $\mathrm{A} \beta \mathrm{PP}$, various $\mathrm{A} \beta \mathrm{PP}$ derivatives, or $\mathrm{A} \beta$. Only in the 1990 s did antibodies against the $\mathrm{C}$-terminus (neopitopes) of $\mathrm{A} \beta\left(\mathrm{A} \beta_{40}\right.$ and $\mathrm{A} \beta_{42}$ ), i.e., antibodies that are able to differentiate $\mathrm{A} \beta$ from $\mathrm{A} \beta \mathrm{PP}$, become available. It is noteworthy that despite the reports indicating that many of the commonly used antibodies are unable to distinguish $\mathrm{A} \beta$ from 
Table 1

Published reports concerning intracellular labeling of $\mathrm{A} \beta$ in human diseases and animal models

\begin{tabular}{|c|c|c|c|c|}
\hline \multirow{2}{*}{$\begin{array}{l}\text { Specificity of } \\
\text { antibody }\end{array}$} & \multicolumn{2}{|c|}{ Materials } & \multirow{2}{*}{$\begin{array}{l}\text { Intracellular } \\
\text { IR of } \mathrm{A} \beta\end{array}$} & \multirow[t]{2}{*}{ Authors, year } \\
\hline & $\begin{array}{l}\text { Study } \\
\text { carried on }\end{array}$ & $\begin{array}{l}\text { Disease / } \\
\text { animal model }\end{array}$ & & \\
\hline \multirow[t]{10}{*}{$\begin{array}{l}\mathrm{A} \beta_{40} \\
\mathrm{mAb} \text { or } \mathrm{pAb}\end{array}$} & Human & Normal & + & $\begin{array}{l}\text { Gouras et al. } 2000 \text { [11], D'Andrea et al. } 2001 \text { [7], Wegiel et al. } \\
2007 \text { [23] }\end{array}$ \\
\hline & & & - & $\begin{array}{l}\text { Gyure et al. } 2001 \text { [13], Nagele et al. } 2002 \text { [17], Cataldo et al. } 2004 \text { [4], } \\
\text { Ohyagi et al.2007 [19] }\end{array}$ \\
\hline & & $\mathrm{AD}$ & + & $\begin{array}{l}\text { Gouras et al. } 2000 \text { [11], D'Andrea et al. } 2001 \text { [7], Cataldo et al. } \\
2004 \text { [4], Wegiel et al. 2007 [23] }\end{array}$ \\
\hline & & & - & Nagele et al. 2002 [17], Ohyagi et al. 2007 [19] \\
\hline & & Down syndrome & + & $\begin{array}{l}\text { Gouras et al. } 2000 \text { [11], Gyure et al. } 2001 \text { [13], Cataldo et al. } 2004 \text { [4], } \\
\text { Wegiel et al. } 2007 \text { [23] [54] }\end{array}$ \\
\hline & & & - & Mori et al. 2002 [16] \\
\hline & Animals & Wild & - & Kuo et al. 2001 [49], VanBroeck et al. 2008 [55] \\
\hline & & Transgenic & + & Lord et al. $2006[33]$ \\
\hline & & & - & Kuo et al. 2001 [49], VanBroeck et al. 2008 [55] \\
\hline & Cell cultures & & + & Gouras et al. $2000[11]$ \\
\hline \multirow[t]{9}{*}{$\begin{array}{l}\mathrm{A} \beta_{42} \\
\mathrm{mAb} \text { or } \mathrm{pAb}\end{array}$} & Human & Normal & + & $\begin{array}{l}\text { Akiyama et al. } 1999 \text { [3], Gouras et al. } 2000 \text { [11], Gyure et al. } \\
2001 \text { [13], Nagele et al. 2002 [17], Cataldo et al. } 2004 \text { [4], Ohyagi et } \\
\text { al. } 2007 \text { [19], D'Andrea et al. 2001; 2002; } 2003 \text { [7,9,39], Wegiel et } \\
\text { al. } 2007 \text { [23] }\end{array}$ \\
\hline & & & - & Mochizuki et al. 2000 [15], Gyure et al. 2001 [13] \\
\hline & & $\mathrm{AD}$ & + & $\begin{array}{l}\text { Akiyama et al. } 1999 \text { [3], Gouras et al. } 2000 \text { [11], Mochizuki et al. } \\
2000 \text { [15], Nagele et al. } 2002 \text { [17], Wang et al. } 2002 \text { [22], Cataldo et } \\
\text { al. } 2004 \text { [4], Ohyagi et al. } 2007 \text { [19], D'Andrea et al. 2001; 2002; } \\
2003 \text { [7-9,39], Wegiel et al. } 2007 \text { [23] }\end{array}$ \\
\hline & & Down syndrome & + & $\begin{array}{l}\text { Gouras et al. } 2000 \text { [11], Gyure et al. } 2001 \text { [13], Mori et al. } 2002 \text { [16], } \\
\text { Cataldo et al. } 2004 \text { [4], Wegiel et al. } 2007 \text { [23] }\end{array}$ \\
\hline & Animals & Wild & + & VanBroeck et al. 2008 [55] \\
\hline & & & - & Kuo et al. 2001 [49] \\
\hline & & Transgenic & + & $\begin{array}{l}\text { Lord et al. } 2006 \text { [33], Oakley et al. } 2006 \text { [18], VanBroeck et al. } \\
2008 \text { [55] }\end{array}$ \\
\hline & & & - & Kuo et al. 2001 [49] \\
\hline & Cell cultures & & + & Gouras et al. 2000 [11], Nagele et al. 2002 [17] \\
\hline \multirow[t]{7}{*}{ clone 4G8 } & Human & Normal & + & $\begin{array}{l}\text { Grunke-Iqbal et al. } 1989 \text { [1], LaFerla et al. } 1997 \text { [14], Akiyama } 1999 \\
\text { et al. [3], Gomez-Ramos et al. } 2007 \text { [10], Ohyagi et al. } 2007 \text { [19], } \\
\text { Wegiel et al. } 2007 \text { [23] }\end{array}$ \\
\hline & & $\mathrm{AD}$ & + & $\begin{array}{l}\text { Grunke-Iqbal et al. } 1989 \text { [1], LaFerla et al. } 1997 \text { [14], Akiyama et } \\
\text { al. } 1999 \text { [3], Cataldo et al. } 2004 \text { [4], Gomez-Ramos et al. } 2007 \text { [10], } \\
\text { Ohyagi et al. } 2007 \text { [19], Wegiel et al. } 2007 \text { [23] }\end{array}$ \\
\hline & & Down syndrome & + & Cataldo et al. 2004 [4], Wegiel et al. 2007 [23] \\
\hline & & HIV & + & Green et al. 2005 [12] \\
\hline & Animals & Wild & + & Cruz et al. 2006 [6], VanBroeck et al. 2008 [55] \\
\hline & & & - & Sheng et al. $2003[21]$ \\
\hline & & Transgenic & + & $\begin{array}{l}\text { Sheng et al. } 2003 \text { [21], Cruz et al. } 2006 \text { [6], Lord et al. } 2006 \text { [33], } \\
\text { Oakley et al. } 2006 \text { [18], VanBroeck et al. 2008 [55] }\end{array}$ \\
\hline \multirow[t]{8}{*}{ clone $6 \mathrm{E} 10$} & Human & Normal & - & Akiyama et al. 1999 [3], Wegiel et al. 2007 [23] \\
\hline & & $\mathrm{AD}$ & - & Akiyama et al. 1999[ [3], Wegiel et al. 2007 [23] \\
\hline & & Down syndrome & - & Wegiel et al. 2007 [23] \\
\hline & & HIV & + & Green et al. 2005 [12] \\
\hline & Animals & Wild & + & Cruz et al. 2006 [6], Kuo et al. 2001 [49] \\
\hline & & & - & VanBroeck et al. 2008 [55] \\
\hline & & Transgenic & + & $\begin{array}{l}\text { Cruz et al. } 2006 \text { [6], Kuo et al. } 2001 \text { [49], Lord et al. } 2006 \text { [33], } \\
\text { Knobloch et al. } 2007 \text { [32] }\end{array}$ \\
\hline & & & - & VanBroeck et al. 2008 [55] \\
\hline \multirow[t]{3}{*}{ clone $6 \mathrm{~F} / 3 \mathrm{D}$} & Human & Normal & - & Akiyama et al. 1999 [3], Wegiel et al. 2007 [23] \\
\hline & & $\mathrm{AD}$ & - & Akiyama et al. 1999 [3], Wegiel et al. 2007 [23] \\
\hline & & Down syndrome & - & Wegiel et al. 2007 [23] \\
\hline
\end{tabular}

IR - immunoreactivity, mAb - monoclonal antibody, pAb - polyclonal antibody, + intracellular IR seen, - no intracellular IR noted. 
$\mathrm{A} \beta \mathrm{PP}$, clone 4G8 was still being used as late as 2009 to detect iA $\beta$ in subjects with HIV [2,12].

In addition to the use of antibodies with variable specificities, the reports listed in Table 1 are carried out on the tissue obtained from either humans or animals. It has earlier been shown that species differences may to some extent influence the findings and thus the results obtained from animal studies are not as such directly comparable with those seen in humans [35, 36]. Therefore, some of the variability listed in Table 1 might be related to species differences. However, even when applying the same antibody or investigating the same species, the results have varied as is seen from Table 1. Another possible explanation for the discrepant results is varying antigen retrieval methods [19,37-40]. It has been demonstrated that a heating protocol can often enhance the staining whereas formic acid pretreatment alone is not sufficient to visualize intracellular immunoreactivity (IR) [19,39]. These reports have concluded that the existence of intracellular labeling may be underestimated, since many previous investigations employed only formic acid pretreatment. In summary, the tissue characteristics, choice of antibody, and modifications of pre-treatments strategy can significantly affect the outcome of an IHC labeling experiment.

The principal objective of this study was to test the reliability of the IHC technique while assessing iA $\beta$ in the routine diagnostic human postmortem material. The presence of $\mathrm{A} \beta \mathrm{PP}$ and $\mathrm{A} \beta$ in the extra- and intracellular compartments was analyzed while applying the tissue microarray technique (TMA), several commercial antibodies, and several antigen retrieval methods.

\section{MATERIAL AND METHODS}

\section{Case selection}

This study was performed on surgical biopsy material and postmortem human brain tissue. The surgical sample was obtained from a patient who underwent intracranial pressure monitoring with frontal cortical biopsy for suspected normal pressure hydrocephalus. The postmortem brain tissues were sampled from the cases that had undergone an autopsy including a neuropathological examination. A total of 26 cases were included in this study; 1 surgical patient and 25 postmortem cases.

\section{Surgical biopsy}

A 75-year old female subject was operated due to normal pressure hydrocephalus. A right frontal $12 \mathrm{~mm}$ burr hole was made under local anesthesia and then cylindrical brain biopsies of $2 \mathrm{~mm}$ in diameter and $3 \mathrm{~mm}$ in length were taken through the burr hole. Half of the sample was fixed in $10 \%$ buffered formalin overnight and then embedded in paraffin. Seven- $\mu$ m-thick serial sections were cut and placed on the SuperFrost ${ }^{\circledR}$ Plusslides. The remaining half of the sample was placed in an Eppendorf tube and frozen at $-70^{\circ} \mathrm{C}$.

\section{Postmortem material}

The demographics of investigated subjects are summarized in Table 2. There were 10 unimpaired subjects (age at death 2-92 years), a 100 year old female with mild cognitive impairment, 7 subjects with AD (age at death 57-87 years), and 7 subjects with frontotemporal lobar degeneration with TAR DNA binding protein 43 positive inclusions (FTLD-TDP-43) (age at death 50-93 years). The rapidity of death was classified as proposed by Hynd and colleagues in 2003 [41]. At autopsy, the brain was placed in $10 \%$ buffered formaldehyde for at least 1 week, and then cut into 1-cm-thick coronal slices. The brain specimens were taken from 16 standard regions and embedded in paraffin. For each case, the AD related Braak stage was assessed as described earlier [42]. Accumulation of eA $\beta$ was assessed in three neocortical sections in all cases while applying clone $4 \mathrm{G} 8$ and the results are given as $\mathrm{A} \beta$ aggregates seen or not seen. The selected neuroanatomical region in the aged was the hippocampal region, in $\mathrm{AD}$ the temporal cortex, and in FTLD-TDP-43 the frontal cortex. The HE stained slides of $7-\mu \mathrm{m}$ thick sections were used to select regions for the core samples to be embedded into the TMA blocks. One of the TMA blocks contained samples from subjects who had been between the ages of 2 to 100 years at death, referred to as the TMA-aging (TMAa) the other TMA block contained samples from demented subjects, i.e., TMA disease (TMAd). From each case in the TMAa, four core samples were taken to ensure the sampling of possible eA $\beta$. For the TMAd from each AD case, a sample from temporal cortex and from each FTLDTDP-43 case, a sample from frontal cortex was taken. Each core in TMAa and TMAd block measured $2.0 \mathrm{~mm}$ in diameter as recommended by Kauppinen and colleagues. The tissue microarray (TMA) block was constructed as described earlier [43,44]. The core tissue sample from the donor blocks was taken using Beecher Instrument's Manual Tissue Arrayer 1 instrument and each core sample was inserted into previously made holes of the recipient block. The maximum 


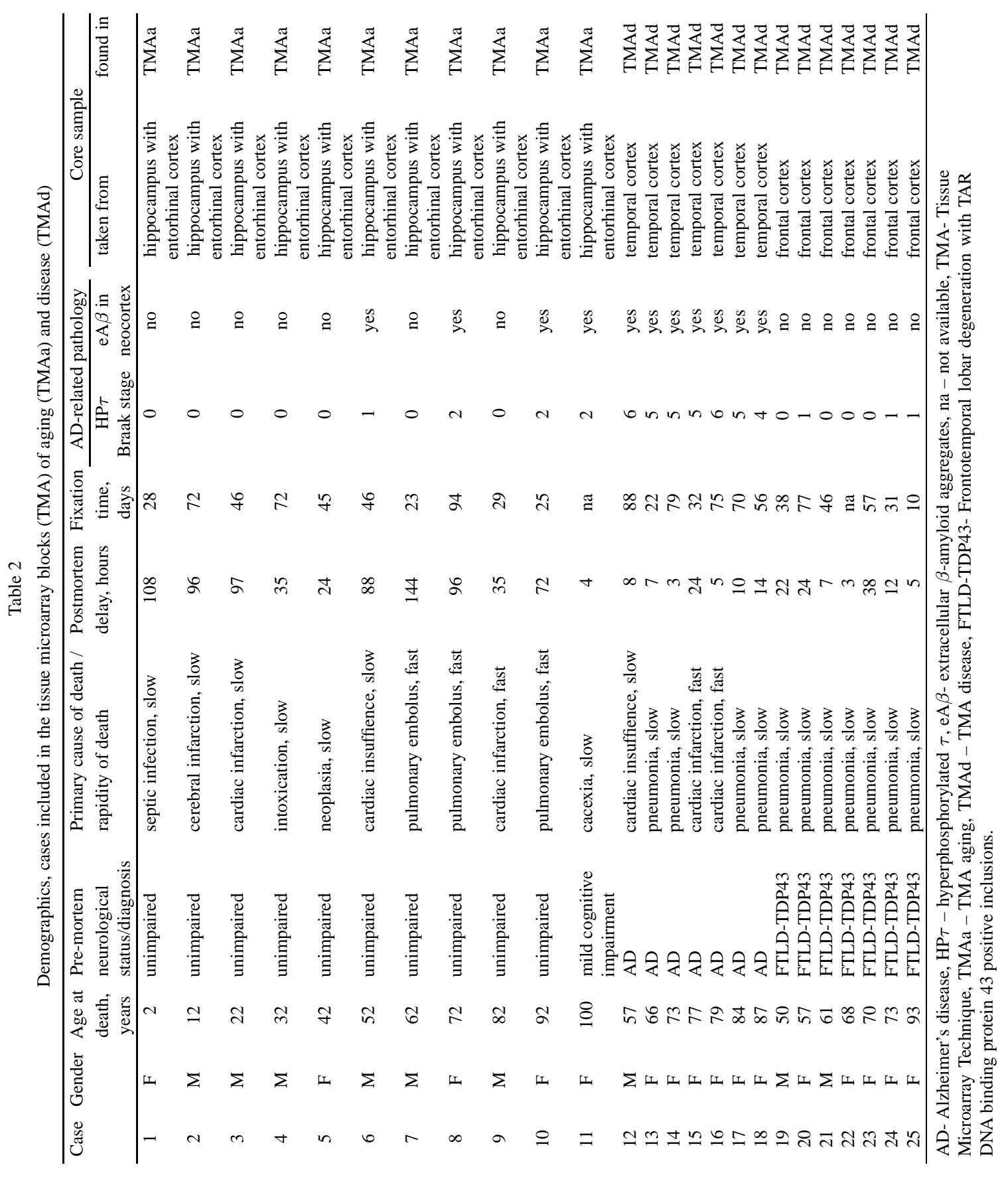


Table 3

Antibodies and dilutions

\begin{tabular}{|c|c|c|c|c|c|}
\hline Name & Source / code & Clone & Immunogen & Dilution & $\begin{array}{l}\text { Material/sections } \\
\text { stained }\end{array}$ \\
\hline Amyloid $\beta(\mathrm{N})$ & $\begin{array}{l}\text { Immuno-Biological } \\
\text { Laboratories / } 10323\end{array}$ & $82 \mathrm{E} 1$ & Recognizes aa residues $1-16$ & $\begin{array}{l}1: 100 \\
1: 500 \\
1: 1000^{\mathrm{a}}\end{array}$ & $\begin{array}{l}\text { TMAa, } \\
\text { TMAa } \\
\text { TMAa, TMAd, b }\end{array}$ \\
\hline Amyloid $\beta \#$ & Signet / 9320 & $6 \mathrm{E} 10$ & $\begin{array}{l}\text { Recognizes aa residues } 1-17 \\
\text { Epitope aa } 4-9\end{array}$ & $\begin{array}{l}1: 1000 \\
1: 2000^{\mathrm{a}} \\
1: 4000\end{array}$ & $\begin{array}{l}\text { TMAа } \\
\text { TMAa, b, \# } \\
\text { TMAa }\end{array}$ \\
\hline Amyloid $\beta$ & Dakocytomation / M0872 & $6 \mathrm{~F} / 3 \mathrm{D}$ & $\begin{array}{l}\text { Recognizes aa residues } 8-17 \\
\text { Epitope aa } 10-15\end{array}$ & $\begin{array}{l}1: 20 \\
1: 50^{\mathrm{a}} \\
1: 100\end{array}$ & $\begin{array}{l}\text { TMAa } \\
\text { TMAa, TMAd } \\
\text { TMAa }\end{array}$ \\
\hline Amyloid $\beta \#$ & Signet / 9220 & 4G8 & $\begin{array}{l}\text { Recognizes aa residues } 17-24 \\
\text { Epitope aa } 18-22\end{array}$ & $\begin{array}{l}1: 1000 \\
1: 2000^{\mathrm{a}} \\
1: 4000\end{array}$ & $\begin{array}{l}\text { TMAа } \\
\text { TMAa, TMAd, b, \# } \\
\text { TMAa }\end{array}$ \\
\hline Amyloid $\beta 40$ & Invitrogen / 44-348 & rabbit & Reactive to aa residues $34-40$ & $\begin{array}{l}1: 500 \\
1: 1000^{\mathrm{a}}\end{array}$ & $\begin{array}{l}\text { TMAa } \\
\text { TMAa, TMAd, b }\end{array}$ \\
\hline Amyloid $\beta 42$ & Invitrogen / 44-344 & rabbit & Reactive to aa residues $36-42$ & $\begin{array}{l}1: 500 \\
1: 1000^{\mathrm{a}}\end{array}$ & $\begin{array}{l}\text { TMAa } \\
\text { TMAa, TMAd, b }\end{array}$ \\
\hline Amyloid $\beta 42$ & Signet & $12 \mathrm{~F} 4$ & Reactive to aa residues $36-42$ & $1: 1000$ & TMAa, TMAd \\
\hline $\begin{array}{l}\text { Amyloid precursor } \\
\text { protein A4\# }\end{array}$ & Chemicon / MAB348 & $22 \mathrm{C} 11$ & $\begin{array}{l}\text { Recognizes aa } 66-81 \text { of the } N \text {-terminus } \\
\text { pre-A } 4 \text { molecule }\end{array}$ & $1: 100^{\mathfrak{T}}$ & TMAa, b, \# \\
\hline $\begin{array}{l}\text { Amyloid precursor } \\
\text { protein }\end{array}$ & Novocastra / NCL-APP & 40.10 & $\begin{array}{l}\text { Recognizes extracellular portion of APP } \\
\text { between the Kunitz protease inhibitor and } \\
\text { the beta-amyloid region }\end{array}$ & $1: 4 \sigma^{2}$ & TMAa, b \\
\hline $\begin{array}{l}\text { Amyloid precursor } \\
\text { protein C-terminal }\end{array}$ & Sigma / A8717 & rabbit & Recognizes the C-terminus of APP & $1: 1000^{\mathfrak{a}}$ & TMAa, b \\
\hline
\end{tabular}

$\mathrm{mAb}$ - monoclonal antibody, pAb - polyclonal antibody, aa - amino acid. ${ }^{\mathrm{a}}$ The optimal dilution to visualize intracytoplasmic labeling. $\mathrm{b}-$ Staining applied on biopsy. \# staining applied on consecutive mirror section. TMAa - tissue microarray block of aging, TMAd-TMA of disease.

depth of the used punch was $8 \mathrm{~mm}$, and the thickness of the recipient block was $10 \mathrm{~mm}$. The resulting TMA blocks were warmed in an oven for $10 \mathrm{~min}$ at $57^{\circ} \mathrm{C}$ to promote the adherence of the core sample to the paraffin of the recipient block. Finally, the TMA blocks were placed upside-down in stainless steel molds for cooling. Seven- $\mu$ m-thick serial sections were cut using a rotating microtome from the TMA blocks and placed on SuperFrost ${ }^{\circledR}$ Plus-slides.

\section{Immunohistochemistry}

Seven- $\mu \mathrm{m}$-thick sections were deparaffinized and rehydrated according to the standard procedure. The TMA sections with the postmortem core samples and the surgical biopsy were stained employing antibodies as described in Table 3 and the following antigen retrieval methods were applied: $80 \%$ formic acid for 2 , 10, $60 \mathrm{~min}$ and for $6 \mathrm{~h}$ or microwave in citrate buffer $\mathrm{pH} 6.03 \times 5 \mathrm{~min}$ or a combination of microwave in citrate buffer $\mathrm{pH} 6.03 \times 5 \mathrm{~min}$ and $80 \%$ formic acid for $10 \mathrm{~min}$. Following the pretreatment, the sections were incubated with normal goat serum for $30 \mathrm{~min}$ at room temperature to block non-specific reactions. After the epitope unmasking, antibodies were applied in the dilution described in Table 3. Then the sections were incubated overnight at $4{ }^{\circ} \mathrm{C}$. On the following day, the sections were incubated with the biotinylated second antibody for 30 min followed by streptavidin enzyme conjugate (LABSA Zymed laboratories, South San Francisco, CA) for $30 \mathrm{~min}$ at room temperature. The reaction product was visualized using romulin 3-amino9-ethyl carbazole (AEC). All immunostained sections were counterstained with Harris' haematoxylin, dehydrated, and mounted in DePex. To confirm the colocalization of positive labeling, serial sections were stained by applying the most optimal staining protocol (Table 3).

The staining results were evaluated under light microscopy. Extracellular and intracellular IR was assessed in each core and the extracellular IR was designated as being present or not. The intracellular IR, which was seen as grainy labeling in the cytoplasm, was noted as seen or not seen. In the serial sections, the colocalization was assessed under light microscopy at low and high magnifications. 


\section{RESULTS}

\section{Extracellular labeling}

All commercial antibodies directed to the amino acid residues present in $\mathrm{A} \beta\left(82 \mathrm{E} 1,6 \mathrm{E} 10,6 \mathrm{~F} 3 \mathrm{D}, 4 \mathrm{G} 8, \mathrm{~A} \beta_{40}\right.$, $\left.\mathrm{A} \beta_{42}, 12 \mathrm{~F} 4\right)$ stained extracellular amyloid deposits irrespective of the antigen retrieval method. Extracellular aggregates were seen in the TMAa in cases \#6, 8,10 , and 11, and as expected, in the TMAd in all cases of $\mathrm{AD}$. The fleecy/diffuse aggregates were seen to the same extent independent of which commercial $\mathrm{A} \beta$ antibody was used. Contrary to the above, antibodies against $\mathrm{A} \beta \mathrm{PP}$ or its derivatives ( $\mathrm{A} \beta \mathrm{PP} \mathrm{C}$-terminal, $\mathrm{A} \beta \mathrm{PP} 40.10)$ did not label the extracellular aggregates.

Formic acid treatment enhanced the intensity of extracellular IR and the contrast increased with up to $60 \mathrm{~min}$ of formic acid pretreatment. The combined pretreatment, i.e., boiling in a microwave oven $3 \times$ $5 \mathrm{~min}$ in citrate buffer and incubation in $80 \%$ formic acid for $10 \mathrm{~min}$, intensified the extent of eA $\beta$ labeling even further, however, the concomitant increase in the background IR decreased the contrast. Intense labeling of amyloid deposits, after boiling in a microwave oven and incubation in formic acid, led to the impression that there was an increased number of compact and a decreased number of diffuse deposits. If the antigen retrieval method was restricted to only boiling in a microwave oven this led to an overall weaker IR staining of the extracellular deposits.

\section{Intracellular labeling}

Intracellular labeling was observed with antibodies against $\mathrm{A} \beta \mathrm{PP}$ or its derivatives in all scores in the TMAa and TMAd regardless of the antigen retrieval method. With three of seven antibodies directed to the amino acid residues present in $\mathrm{A} \beta$ (82E1, 6E10, 4G8), an obvious granular intracellular labeling was seen in all scores in the TMAa and TMAd and the labeling was present in cells already at the age of 2 and the IR remained high in all samples over entire age range of 2 to 100 years. The labeled grains were small and coarse and located close to the nucleus. With antibodies $\mathrm{A} \beta_{40}$, $\mathrm{A} \beta_{42}$, and $12 \mathrm{~F} 4$, intracellular labeling was only detected in the TMAd in cores taken from the temporal cortex of AD cases $(n=7)$. The monoclonal antibody 6F3D did not display intracellular IR in any of the cores in the TMAa or TMAd. The mode of death did not seem to alter the amount of intracellular IR.
Antibodies directed to the $\mathrm{N}$-terminus or mid portion of $A \beta$

The monoclonal antibody against $\mathrm{N}$-terminus of $\mathrm{A} \beta$, $6 \mathrm{~F} 3 \mathrm{D}$, did not display intracellular IR regardless of which antigen retrieval method was used in any of the cores in the TMAa or TMAd. Contrary to the above, with monoclonal antibody directed to the mid-portion of $\mathrm{A} \beta$, clone $4 \mathrm{G} 8$, intracellular labeling was seen in all TMAa and TMAd cores irrespective of age, disease state, or antigen retrieval method. However, a more intense intracellular labeling was detected in sections pretreated with heating as compared to those pretreated with formic acid. The intracellular labeling with $\mathrm{N}$-terminal monoclonal antibody 6E10 was detected in the cores in TMAa and TMAd only when the combined pretreatment, i.e., boiling in the microwave oven and incubation in formic acid was used. In line with the above, when the $\mathrm{N}$-terminal monoclonal antibody clone 82E1 was used, then intracellular labeling was noted with the high magnification in most cores in the TMAa (Fig. 2) and in the TMAd in two AD cases (\#13, $15)$, and in three FTLD-TDP43 cases (\#21, 22, 25) but only when the combination of heat and formic acid pretreatment was used. While applying clone 82E1, a few cells with labeling were noted in TMAa in the 2year old child at the $x 200$ magnification, whereas in the oldest case with additional eA $\beta$ aggregates, iA $\beta$ labeling was seen in almost every cell. To summarize, the combination of heat and formic acid was essential to visualize the intracellular staining with antibodies such as $6 \mathrm{E} 10$ and $82 \mathrm{E} 1$, whereas the intracellular staining with monoclonal antibody 4G8 was seen regardless of antigen retrieval method.

When comparing the images of serial sections and assessing neurons with identifiable nuclei, intracellular labeling was noted in the same cell with antibodies 4G8 or $6 \mathrm{E} 10$ and $\mathrm{A} \beta \mathrm{PP} 22 \mathrm{C} 11$ (Fig. 3).

\section{Antibodies directed to the $C$-terminus of $A \beta$}

The intracellular staining with the polyclonal antibodies directed to the neoepitopes, $\mathrm{A} \beta_{40}$ and $\mathrm{A} \beta_{42}$, and the monoclonal antibody $\mathrm{A} \beta_{42}$, was not detected in the cores in TMAa, even though four of the TMAa core samples displayed additional eA $\beta$ (\#6, 8, 10, and 11). Interestingly in the TMAd, intracellular labeling was seen with both mono- and polyclonal $\mathrm{A} \beta$ antibodies in all cores taken from the temporal cortex of AD cases $(n=7)$ displaying eA $\beta$ aggregates, most being in Braak stages V to VI (Table 2, Fig. 4). The labeling 


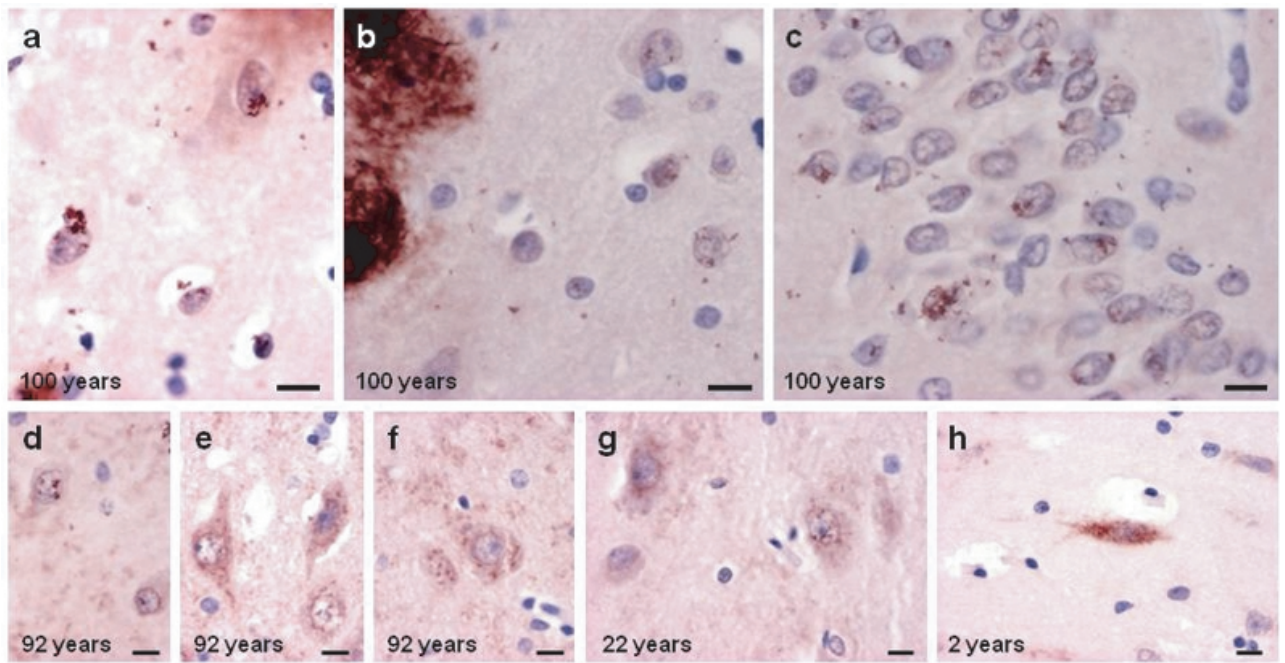

Fig. 2. Photomicrographs displaying the $82 \mathrm{E} 1$ positive grainy perinuclear/intracellular labeling seen in the hippocampal cells in a 100 year old subject (a-c), in a 92 year old subject (d-f), in a 22 year old subjects (g) and in the 2 year old child (h). Scale bar $=10 \mu \mathrm{m}$.
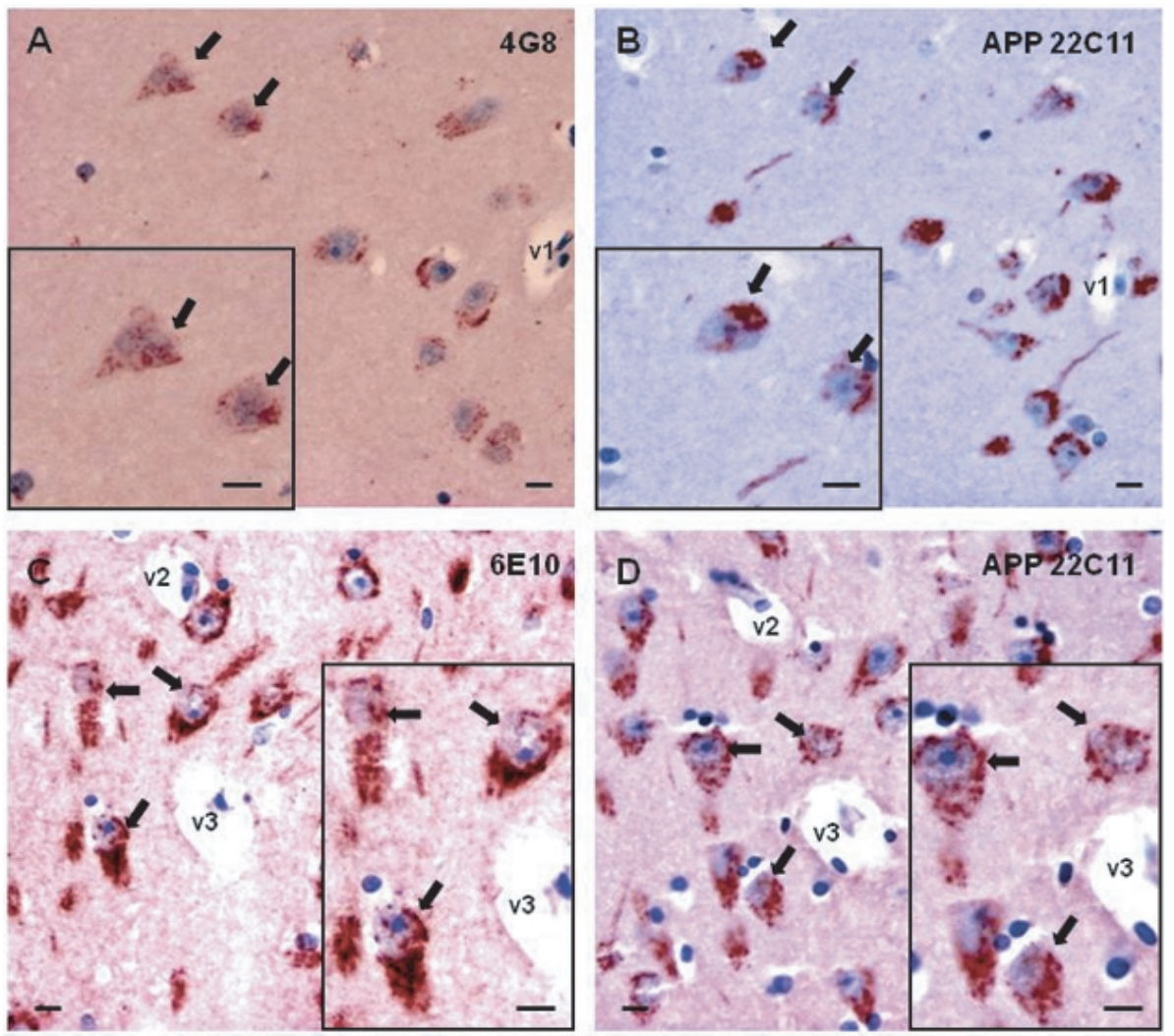

Fig. 3. Application of clones 4G8, 6E10 and A $\beta \mathrm{PP} 22 \mathrm{C} 11$ on serial sections. 4G8 and $6 \mathrm{E} 10$ positive neurons (a, c) bisected during sectioning (arrows, enlarged in insets) were identified in the adjacent A $\beta$ PP-stained sections (b, d) using nearby vessels (v1-3) as landmarks. Scale bars $=$ $10 \mu \mathrm{m}$. 

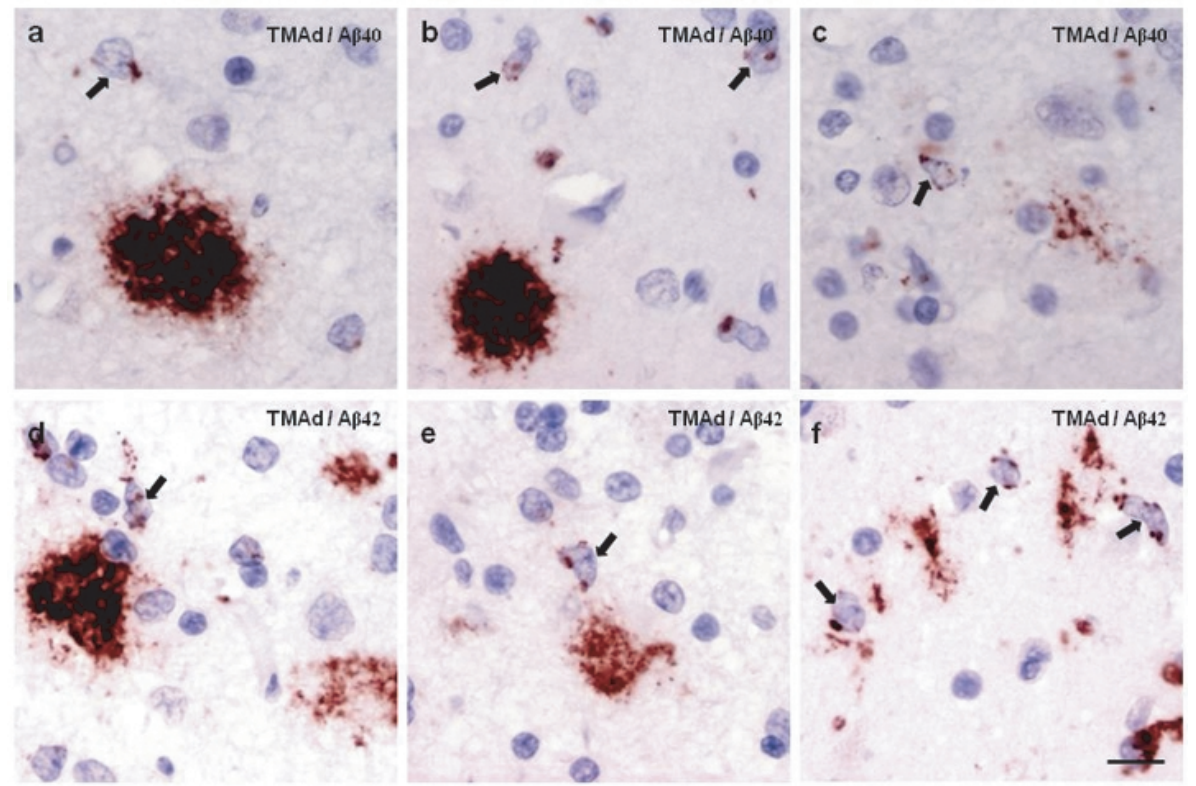

Fig. 4. The intracellular labeling of $\mathrm{A} \beta$ in the TMA block of disease with the polyclonal antibodies $\mathrm{A} \beta_{40}$ and $\mathrm{A} \beta_{42}$. Note a grainy perinuclear/intracellular labeling (neurons or glial cells) in core samples where in addition extracellular A $\beta$ IR aggregates were seen. Scale bar $=10 \mu \mathrm{m}$.
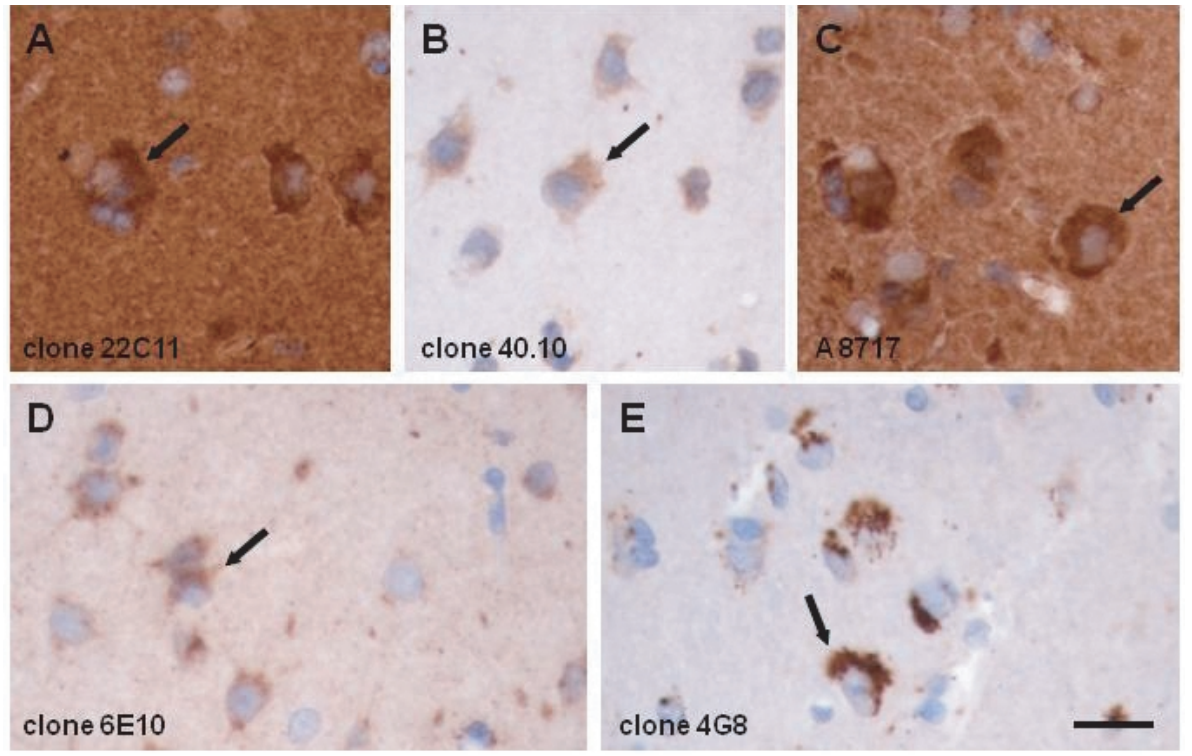

Fig. 5. A brain biopsy obtained from frontal cortex from a 75 year-old female was immunohistochemically stained while applying antibodies as given in the Fig. 1 and Table 3. Note that with all antibodies intracytoplasmic perinuclear grainy labeling was seen. Some antibodies directed to $\mathrm{A} \beta \mathrm{PP}$ also strongly labeled the neuropil. 
was seen at the high magnification and based on the cytological features; the cells were either neurons or glial cells. It is noteworthy that some labeled grains were also seen in the neuropil complicating the interpretation of the staining results. These results were obtained regardless of which of the following antigen retrieval method was used: $80 \%$ formic acid, or microwave in citrate buffer $\mathrm{pH} 6.03 \times 5 \mathrm{~min}$, or a combination of microwave in citrate buffer pH $6.03 \times 5 \mathrm{~min}$ and $80 \%$ formic acid for $10 \mathrm{~min}$.

\section{Surgical sample}

In the surgical biopsy, no eA $\beta$ aggregates were seen with any of the applied antibodies. Intracellular labeling was seen with antibodies 6E10, 4G8, 82E1, $\mathrm{A} \beta \mathrm{PP} 22 \mathrm{C} 11, \mathrm{~A} \beta \mathrm{PP} 40.10$, and $\mathrm{A} \beta \mathrm{PP} \mathrm{C}$-terminus (Fig. 5). No IR was seen when applying mono- or polyclonal C-terminal $\mathrm{A} \beta$ antibodies.

\section{DISCUSSION}

In the present study, the $\mathrm{eA} \beta$ IR was repeatedly detected with antibodies directed to the amino acid residues present in the $\mathrm{A} \beta$, whereas no extracellular IR was noted with antibodies directed to the $\mathrm{A} \beta \mathrm{PP}$ or its derivatives. This finding confirms earlier reports that extracellular aggregates consist of $\mathrm{A} \beta$ rather than $\mathrm{A} \beta \mathrm{PP}$. In contrast to the clear results with respect to the extracellular labeling, the staining results regarding the iA $\beta$ were variable and dependent on both the chosen antibody and the antigen retrieval method.

Seven different commercial antibodies (4G8, 6E10, 82E1, 6F3D, $\left.\mathrm{A} \beta_{40}, \mathrm{~A} \beta_{42}, 12 \mathrm{~F} 4\right)$ directed to the $\mathrm{N}$ - or $\mathrm{C}$-terminus or mid-portion of the $\mathrm{A} \beta$ fragment were used in the present study. All of these antibodies have been claimed to recognize $\mathrm{A} \beta$ in the tissue according to their specifications. With three (4G8, 6E10, 82E1) of these seven antibodies, intracellular IR was detected in all cases in the cores in TMAa and TMAd independent of disease state, and it is noteworthy that the IR was already seen at the age of two years. Contrary to the above, with the $\mathrm{C}$-terminal antibodies, i.e., $\mathrm{A} \beta_{40}$, $\mathrm{A} \beta_{42}$, and $12 \mathrm{~F} 4$, the $\mathrm{iA} \beta$ IR was only detected in the $\mathrm{AD}$ cases. Interestingly, monoclonal antibody $6 \mathrm{~F} 3 \mathrm{D}$ did not label the intracellular compartment with any of the used techniques in any of the cores. Hence, if only the antibodies against $\mathrm{N}$-terminus or the mid-portion of the $\mathrm{A} \beta$ had been applied, the conclusion would have been that the $\mathrm{iA} \beta$ is seen in all cases from 2 year old up to 100 year old irrespective of condition. This is in agreement with reports claiming that the $\mathrm{iA} \beta$ represents a product of normal neuronal metabolism [23, $25,34]$. On the contrary, if only the antibodies directed to $\mathrm{C}$-terminus of the $\mathrm{A} \beta$ had been used, the conclusion would have been that the $\mathrm{iA} \beta$ is only detected in the brains of subjects with $\mathrm{AD}$, and this would confirm the reports suggesting that the accumulation of $\mathrm{iA} \beta$ is an event associated with the pathogenesis of $\mathrm{AD}[4,7,11$, $13,17,45]$. These results emphasize that the obtained staining results and their interpretation are strongly dependent on the choice of antibody and thus, it has to be concluded that indeed multiple antibodies, including antibodies directed to the $\mathrm{N}$ - and $\mathrm{C}$-terminal neoepitopes, must be used when assessing the presence of iA $\beta$ [46].

In the present study, in all cases (TMAa and TMAd) independent of disease state or age intracellular staining was seen with the antibodies 4G8, 6E10, and 82E1. The assessment of mirror images of consecutive sections revealed that not only the $\mathrm{A} \beta$ clones $4 \mathrm{G} 8$ and $6 \mathrm{E} 10$ but also the $\mathrm{A} \beta \mathrm{PP} 22 \mathrm{C} 11$ labeled the cytoplasm of the same cell. In 1996, LeBlanc and co-workers demonstrated that the clone 4G8 immunoprecipitated not only $\mathrm{A} \beta$ but also the full-length $\mathrm{A} \beta \mathrm{PP}$ and $\mathrm{A} \beta \mathrm{PP}$ C-terminal fragment [47]. This finding was further confirmed in 2002 by Takahashi and colleagues who reported that clone $4 \mathrm{G} 8$ reacted with $\mathrm{A} \beta \mathrm{PP} \mathrm{C}$-terminal fragments in Western blotting [34]. The antibodies directed close to the $\mathrm{N}$-terminus may theoretically also recognize $\mathrm{A} \beta$ that is still embedded in the membrane. The amino acid sequence that is recognized by clones $4 \mathrm{G} 8$ and $6 \mathrm{E} 10$ is also found in the full-length $\mathrm{A} \beta \mathrm{PP}$ and its derivatives, hence these antibodies are unable to differentiate $\mathrm{A} \beta$ from $\mathrm{A} \beta \mathrm{PP}[32,33,47,48]$. The clone $82 \mathrm{E} 1$ that detects fragments generated by $\beta$-secretase cleavage [48] labels both soluble and insoluble $\mathrm{A} \beta$ to a similar degree and recognizes the free $\mathrm{N}$-terminus of the A $\beta$ PP C99 fragment and this C99 fragment is then later cleaved by the $\gamma$-secretase to generate $\mathrm{A} \beta$. Therefore, the detection of intracellular IR with clone 82E1 only indicates that the cleavage product of $\beta$-secretase is present in the intracellular compartment. The commonly used antibodies such as 4G8, 6E10, and 82E1 fail to distinguish $\mathrm{A} \beta$ from $\mathrm{A} \beta \mathrm{PP}$ if examined by IHC. Thus, one must question the validity of reports claiming that it is $\mathrm{A} \beta$ rather than $\mathrm{A} \beta \mathrm{PP}$ that is present in the intracellular compartment if antibodies such as 4G8, $6 \mathrm{E} 10$, and 82E1 have been utilized (Table 1).

The accumulation of iA $\beta$ has also been reported while applying commercial antibodies directed to the 
C-terminus of $\mathrm{A} \beta$ (neoepitope) that have been reported to be specific to $\mathrm{A} \beta[3,4,7-9,11,13,15-17,19,22,23$, 39]. In the present study, while applying commercial antibodies directed to the C-terminus of $\mathrm{A} \beta$, an intense $\mathrm{eA} \beta$ IR (positive control) was seen in the TMAa and TMAd core samples. In the TMAa, no iA $\beta$ was detected in any of the cores irrespective of whether or not additional eA $\beta$ was seen. Our negative result, i.e., lack of intracellular labeling while applying antibodies directed to $\mathrm{A} \beta_{40}$ and $\mathrm{A} \beta_{42}$ is confirmation of the reports of Kuo and co-workers and Mochizuki and coworkers $[15,49]$. Contrary to the above, in all subjects with $\mathrm{AD}$, intracellular IR was indeed detected with the antibodies directed to $\mathrm{C}$-terminal neoepitopes $\mathrm{A} \beta_{40}$ and $\mathrm{A} \beta_{42}$. The presence of $\mathrm{iA} \beta$ in subjects with additional $\mathrm{e} A \beta$ aggregates and widespread neuronal degeneration (Braak stages IV to VI) and the absence of $\mathrm{iA} \beta$ in subjects without additional eA $\beta$ aggregates does suggest that it is the internalization of $\mathrm{A} \beta$ from the extracellular pool rather than the intracellular production of $\mathrm{A} \beta$ is accelerated. This finding is in line with several previous studies reporting the presence of $\mathrm{iA} \beta$ in the $\mathrm{AD}$ brains [3,4,7-9,11,15,17,19,22,23,39]. In 2008, Aoki and colleagues, while using laser capture micro dissection to isolate neurons of hippocampus, noted iA $\beta_{42}$ in all investigated subjects [50]. They detected a significant increase in the level of $\mathrm{iA} \beta_{42}$ in AD subjects when compared with controls (mean age ranging from 71 to 90) and the highest levels were seen in subjects with familial disease [50]. Thus, the lack of IR in the brains obtained from subjects without neuronal degeneration may indicate that the level of the $\mathrm{iA} \beta$ is very low, undetectable at the light microscopic level by IHC methods. In conclusion, our and previous results indicate that iA $\beta$ labeling with the specific antibodies can indeed be seen at the light microscopy level and this is associated with eA $\beta$ labeling but only in tissue samples obtained from diseased brains with widespread neuronal degeneration.

The antigen retrieval method, re-exposing and reshaping the critical epitopes, is significant as is shown in this study while applying clones $6 \mathrm{E} 10$ and 82E1 [5, 19,21,37-39]. Formic acid is a widely used antigen retrieval method to enhance the IR of $\mathrm{eA} \beta$, whereas the effect of formic acid pretreatment on the $\mathrm{iA} \beta$ is less clear. In the present study, the intracellular IR with clones $6 \mathrm{E} 10$ and 82E1 was only seen when the sections were both heated and incubated in formic acid indicating that heat pretreatment was essential for the staining of $\mathrm{iA} \beta$ with these antibodies. This result is in line with previous publications stating that formic acid pretreatment alone is not sufficient to visualize the intracellular IR $[19,39]$. In the recently published study of Christensen and colleagues, it was demonstrated that heat alone increases the cross-reaction at least of clone 4G8 and A $\beta \mathrm{PP}$ [5], i.e., this heat-induced cross-reaction may explain the more intense intracellular IR with clone 4G8. This result corroborates that it is $\mathrm{A} \beta \mathrm{PP}$ rather than $\mathrm{A} \beta$ that is present in the intracellular compartment with antibody such as 4G8. The other antibody directed close to the $\mathrm{N}$-terminus of the $\mathrm{A} \beta$, clone $6 \mathrm{~F} 3 \mathrm{D}$, repeatedly failed to label the intracellular compartment even though the extracellular labeling of aggregates was excellent. As far as we are aware, no intracellular labeling with clone 6F3D has been so far detected. Whether this is due to poor preservation of the epitope during pre-sectioning treatment, the spatial configuration of the protein, or the localization of the epitopes within the protein, is currently unknown [40, 51].

In addition to the antibody and the antigen retrieval method, species differences may also influence on the staining results $[35,36]$. All widely used transgenic mice models are based on $\mathrm{A} \beta \mathrm{PP}$ mutations that are known to influence the production and aggregation of $\mathrm{A} \beta_{42}$ peptide and thus $\mathrm{A} \beta$ peptides in transgenic mice models are in a higher aggregation state when compared to humans [5]. Moreover, it has been shown in vivo that transcription factors responsible for gene expression diverge between human and mouse [52]. Lately the epigenetic alterations have been linked to the development of neurological disorders such as AD and Parkinson disease [53]. It can be expected that like transcription factors also the epigenetic factors, DNA methylation and histone modifications, diverge between human and animals. These physiological differences affect all studies that use the mouse as a model for human biology [52]. Therefore, the results obtained from animal studies are not as such directly comparable with results obtained while studying brain tissue obtained from humans.

As shown in the present study, the obtained staining results are strongly dependent on the applied antibody, antigen retrieval method, and the tissue characteristics. Furthermore, it should be noted that the interpretation of the results while applying one and the same antibody has been contradictory, i.e., in one study the IR has been interpreted as representing $\mathrm{A} \beta$ and in another as $\mathrm{A} \beta \mathrm{PP}[3,32,33]$. Summarizing all the available reports (Table 1) and our own results, we conclude that at the light microscopic level it is not possible to differentiate $\mathrm{A} \beta$ from $\mathrm{A} \beta \mathrm{PP}$, when monoclonal antibodies such 
as $4 \mathrm{G} 8,6 \mathrm{E} 10$, and $82 \mathrm{E} 1$ have been used. In routine diagnostics while assessing the extracellular accumulation of $\mathrm{A} \beta$, these antibodies are commendable, but they are not useful if one is trying to investigate the intracellular accumulation of $\mathrm{A} \beta$. When the goal is to assess $\mathrm{A} \beta$ protein, and to determine whether protein is localized in the intracellular space, then antibody directed to neoepitopes that recognize the site of terminal sequence of $\mathrm{A} \beta$ and which are able to differentiate $\mathrm{A} \beta$ from $\mathrm{A} \beta \mathrm{PP}$ should be used. In conclusion, if one wishes to unambiguously confirm the presence or absence of a protein in tissue, multiple antibodies directed to several different amino acid sequences should be used and the significant influence of antigen retrieval methods should also always be considered.

\section{ACKNOWLEDGMENTS}

We thank Erkki Kuusisto, PhD, Mrs. Tarja Kauppinen, Mrs. Merja Fali, Mr. Heikki Luukkonen, and Mr. Hannu Tiainen for their valuable help. This study was supported by European Union grant FP6: BNEII No LSHM-CT-2004-503039, the Finnish Cultural Foundation, Health Research Council of the Academy of Finland, EVO grant 5772708 of Kuopio University Hospital, and the Nordic Centre of Excellence of Neurodegeneration. This article reflects only the authors' views and that the Community is not liable for any use that may be made of the information contained therein. The study has been authorized by the Ethics Committee of Kuopio University Hospital. Source of support: EU grant FP6: BNEII No LSHMCT-2004-503039.

Authors' disclosures available online (http://www.jalz.com/disclosures/view.php?id=303).

\section{REFERENCES}

[1] Grundke-Iqbal I, Iqbal K, George L, Tung YC, Kim KS, Wisniewski HM (1989) Amyloid protein and neurofibrillary tangles coexist in the same neuron in Alzheimer disease. Proc Natl Acad Sci U S A 86, 2853-2857.

[2] Achim CL, Adame A, Dumaop W, Everall IP, Masliah E, Neurobehavioral Research Center (2009) Increased accumulation of intraneuronal amyloid beta in HIV-infected patients. J Neuroimmune Pharmacol 4, 190-199.

[3] Akiyama H, Mori H, Saido T, Kondo H, Ikeda K, McGeer PL (1999) Occurrence of the diffuse amyloid beta-protein (Abeta) deposits with numerous Abeta-containing glial cells in the cerebral cortex of patients with Alzheimer's disease. Glia 25, 324-331.
[4] Cataldo AM, Petanceska S, Terio NB, Peterhoff CM, Durham R, Mercken M, Mehta PD, Buxbaum J, Haroutunian V, Nixon RA (2004) Abeta localization in abnormal endosomes: association with earliest Abeta elevations in AD and Down syndrome. Neurobiol Aging 25, 1263-1272.

[5] Christensen DZ, Bayer TA, Wirths O (2009) Formic acid is essential for immunohistochemical detection of aggregated intraneuronal Abeta peptides in mouse models of Alzheimer's disease. Brain Res 1301, 116-125.

[6] Cruz JC, Kim D, Moy LY, Dobbin MM, Sun X, Bronson RT, Tsai LH (2006) P25/cyclin-Dependent Kinase 5 Induces Production and Intraneuronal Accumulation of Amyloid Beta in Vivo. J Neurosci 26, 10536-10541.

[7] D'Andrea MR, Peterson PA, Lee DH, Nagele RG, Wang HY (2001) Evidence that neurones accumulating amyloid can undergo lysis to form amyloid plaques in Alzheimer's disease. Histopathology 38, 120-134.

[8] D'Andrea MR, Nagele RG, Gumula NA, Reiser PA, Polkovitch DA, Hertzog BM, Andrade-Gordon P (2002) Lipofuscin and $\mathrm{A} \beta 42$ exhibit distinct distribution patterns in normal and Alzheimer's disease brains. Neurosci Lett 323, 45-49.

[9] D'Andrea MR, Lee DHS, Nagele RG, Wang H (2002) Consistent immunohistochemical detection of intracellular betaamyloid42 in pyramidal neurons of Alzheimer's disease entorhinal cortex. Neurosci Lett 333, 163-166.

[10] Gomez-Ramos P, Asuncion Moran M (2007) Ultrastructural localization of intraneuronal Abeta-peptide in Alzheimer disease brains. J Alzheimers Dis 11, 53-59.

[11] Gouras GK, Tsai J, Naslund J, Vincent B, Edgar M, Checler F, Greenfield JP, Haroutunian V, Buxbaum JD, Xu H, Greengard P, Relkin NR (2000) Intraneuronal Abeta42 accumulation in human brain. Am J Pathol 156, 15-20.

[12] Green DA, Masliah E, Vinters HV, Beizai P, Moore DJ, Achim CL (2005) Brain deposition of beta-amyloid is a common pathologic feature in HIV positive patients. AIDS 19, 407-411.

[13] Gyure KA, Durham R, Stewart WF, Smialek JE, Troncoso JC (2001) Intraneuronal abeta-amyloid precedes development of amyloid plaques in Down syndrome. Arch Pathol Lab Med 125, 489-492.

[14] LaFerla FM, Troncoso JC, Strickland DK, Kawas CH, Jay G (1997) Neuronal cell death in Alzheimer's disease correlates with apoE uptake and intracellular Abeta stabilization. J Clin Invest 100, 310-320.

[15] Mochizuki A, Tamaoka A, Shimohata A, Komatsuzaki Y, Shoji S (2000) Abeta42-positive non-pyramidal neurons around amyloid plaques in Alzheimer's disease. Lancet 355, 42-43.

[16] Mori C, Wisniewski TM, Tolan DR, Yamaguch H, Spooner ET, Wisniewsk KE, Lemere CA, Saido TC, Selkoe DJ (2002) Intraneuronal Abeta42 accumulation in Down syndrome brain. Amyloid 9, 88-102.

[17] Nagele RG, D'Andrea MR, Anderson WJ, Wang HY (2002) Intracellular accumulation of beta-amyloid(1-42) in neurons is facilitated by the alpha 7 nicotinic acetylcholine receptor in Alzheimer's disease. Neuroscience 110, 199-211.

[18] Oakley H, Cole SL, Logan S, Maus E, Shao P, Craft J, Guillozet-Bongaarts A, Ohno M, Disterhoft J, Van Eldik L, Berry R, Vassar R (2006) Intraneuronal beta-amyloid aggregates, neurodegeneration, and neuron loss in transgenic mice with five familial Alzheimer's disease mutations: potential factors in amyloid plaque formation. J Neurosci 26, 1012910140.

[19] Ohyagi Y, Tsuruta Y, Motomura K, Miyoshi K, Kikuchi H, Iwaki T, Taniwaki T, Kira J (2007) Intraneuronal amyloid 
beta42 enhanced by heating but counteracted by formic acid. J Neurosci Methods 159, 134-138.

[20] Ramage SN, Anthony IC, Carnie FW, Busuttil A, Robertson R, Bell JE (2005) Hyperphosphorylated tau and amyloid precursor protein deposition is increased in the brains of young drug abusers. Neuropathol Appl Neurobiol 31, 439-448.

[21] Sheng JG, Bora SH, Xu G, Borchelt DR, Price DL, Koliatsos VE (2003) Lipopolysaccharide-induced-neuroinflammation increases intracellular accumulation of amyloid precursor protein and amyloid beta peptide in APPswe transgenic mice. Neurobiol Dis 14, 133-145.

[22] Wang HY, D’Andrea MR, Nagele RG (2002) Cerebellar diffuse amyloid plaques are derived from dendritic Abeta42 accumulations in Purkinje cells. Neurobiol Aging 23, 213-223.

[23] Wegiel J, Kuchna I, Nowicki K, Frackowiak J, Mazur-Kolecka B, Imaki H, Wegiel J, Mehta PD, Silverman WP, Reisberg B, Deleon M, Wisniewski T, Pirttilla T, Frey H, Lehtimaki T, Kivimaki T, Visser FE, Kamphorst W, Potempska A, Bolton D, Currie JR, Miller DL (2007) Intraneuronal Abeta immunoreactivity is not a predictor of brain amyloidosis-beta or neurofibrillary degeneration. Acta Neuropathol 113, 389-402.

[24] Glenner GG, Wong CW (1984) Alzheimer's disease and Down's syndrome: sharing of a unique cerebrovascular amyloid fibril protein. Biochem Biophys Res Commun 122, 11311135 .

[25] Haass C, Schlossmacher MG, Hung AY, Vigo-Pelfrey C, Mellon A, Ostaszewski BL, Lieberburg I, Koo EH, Schenk D, Teplow DB (1992) Amyloid beta-peptide is produced by cultured cells during normal metabolism. Nature 359, 322-325.

[26] Masters CL, Simms G, Weinman NA, Multhaup G, McDonald BL, Beyreuther K (1985) Amyloid plaque core protein in Alzheimer disease and Down syndrome. Proc Natl Acad Sci U S A 82, 4245-4249.

[27] Miller DL, Papayannopoulos IA, Styles J, Bobin SA, Lin YY, Biemann K, Iqbal K (1993) Peptide compositions of the cerebrovascular and senile plaque core amyloid deposits of Alzheimer's disease. Arch Biochem Biophys 301, 41-52.

[28] Tanzi RE, McClatchey AI, Lamperti ED, Villa-Komaroff L, Gusella JF, Neve RL (1988) Protease inhibitor domain encoded by an amyloid protein precursor mRNA associated with Alzheimer's disease. Nature 331, 528-530.

[29] Kinoshita A, Fukumoto H, Shah T, Whelan CM, Irizarry MC, Hyman BT (2003) Demonstration by FRET of BACE interaction with the amyloid precursor protein at the cell surface and in early endosomes. J Cell Sci 116, 3339-3346.

[30] Xu H, Greengard P, Gandy S (1995) Regulated formation of Golgi secretory vesicles containing Alzheimer beta-amyloid precursor protein. J Biol Chem 270, 23243-23245.

[31] Mizuguchi M, Ikeda K, Kim SU (1992) Differential distribution of cellular forms of beta-amyloid precursor protein in murine glial cell cultures. Brain Res 584, 219-225.

[32] Knobloch M, Konietzko U, Krebs DC, Nitsch RM (2007) Intracellular Abeta and cognitive deficits precede beta-amyloid deposition in transgenic arcAbeta mice. Neurobiol Aging 28, 1297-1306.

[33] Lord A, Kalimo H, Eckman C, Zhang XQ, Lannfelt L, Nilsson LN (2006) The Arctic Alzheimer mutation facilitates early intraneuronal Abeta aggregation and senile plaque formation in transgenic mice. Neurobiol Aging 27, 67-77.

[34] Takahashi RH, Milner TA, Li F, Nam EE, Edgar MA, Yamaguchi H, Beal MF, Xu H, Greengard P, Gouras GK (2002) Intraneuronal Alzheimer abeta42 accumulates in multivesicular bodies and is associated with synaptic pathology. Am J Pathol 161, 1869-1879.
[35] Harding AJ, Wong A, Svoboda M, Kril JJ, Halliday GM (1997) Chronic alcohol consumption does not cause hippocampal neuron loss in humans. Hippocampus 7, 78-87.

[36] Mandavilli A (2006) The amyloid code. Nat Med 12, 747-751.

[37] Alafuzoff I, Pikkarainen M, Arzberger T, Thal DR, Al-Sarraj S, Bell J, Bodi I, Budka H, Capetillo-Zarate E, Ferrer I, Gelpi E, Gentleman S, Giaccone G, Kavantzas N, King A, Korkolopoulou P, Kovacs GG, Meyronet D, Monoranu C, Parchi P, Patsouris E, Roggendorf W, Stadelmann C, Streichenberger N, Tagliavini F, Kretzschmar H (2008) Inter-laboratory comparison of neuropathological assessments of beta-amyloid protein: a study of the BrainNet Europe consortium. Acta Neuropathol 115, 533-546.

[38] Beach TG, Sue LI, Walker DG, Roher AE, Lue L, Vedders L, Connor DJ, Sabbagh MN, Rogers J (2008) The Sun Health Research Institute Brain Donation Program: description and experience, 1987-2007. Cell Tissue Bank 9, 229-245.

[39] D'Andrea MR, Reiser PA, Polkovitch DA, Gumula NA, Branchide B, Hertzog BM, Schmidheiser D, Belkowski S, Gastard MC, Andrade-Gordon P (2003) The use of formic acid to embellish amyloid plaque detection in Alzheimer's disease tissues misguides key observations. Neurosci Lett 342, 114-118.

[40] Shi SR, Cote RJ, Taylor CR (1997) Antigen retrieval immunohistochemistry: past, present, and future. J Histochem Cytochem 45, 327-343.

[41] Hynd MR, Lewohl JM, Scott HL, Dodd PR (2003) Biochemical and molecular studies using human autopsy brain tissue. J Neurochem 85, 543-562.

[42] Alafuzoff I, Arzberger T, Al-Sarraj S, Bodi I, Bogdanovic N, Braak H, Bugiani O, Del-Tredici K, Ferrer I, Gelpi E, Giaccone G, Graeber MB, Ince P, Kamphorst W, King A, Korkolopoulou P, Kovacs GG, Larionov S, Meyronet D, Monoranu C, Parchi P, Patsouris E, Roggendorf W, Seilhean D, Tagliavini F, Stadelmann C, Streichenberger N, Thal DR, Wharton SB, Kretzschmar H (2008) Staging of neurofibrillary pathology in Alzheimer's disease: a study of the BrainNet Europe Consortium. Brain Pathol 18, 484-496.

[43] Kauppinen T, Martikainen P, Alafuzoff I (2006) Human postmortem brain tissue and 2-mm tissue microarrays. Appl Immunohistochem Mol Morphol 14, 353-359.

[44] Martikainen P, Louhelainen AM, Kauppinen T, Alafuzoff I (2006) Human brain tissue microarrays as a platform to investigate diseases of the nervous system. Brain Res 1089, 33-43.

[45] Wirths O, Multhaup G, Bayer TA (2004) A modified betaamyloid hypothesis: intraneuronal accumulation of the betaamyloid peptide-the first step of a fatal cascade. J Neurochem 91, 513-520.

[46] LaFerla FM, LaFerla FM, Green KN, Oddo S (2007) Intracellular amyloid-\&beta; in Alzheimer's disease. Nat Rev Neurosci $\mathbf{8}, 499$.

[47] LeBlanc AC, Xue R, Gambetti P (1996) Amyloid precursor protein metabolism in primary cell cultures of neurons, astrocytes, and microglia. J Neurochem 66, 2300-2310.

[48] Horikoshi Y, Sakaguchi G, Becker AG, Gray AJ, Duff K, Aisen PS, Yamaguchi H, Maeda M, Kinoshita N, Matsuoka Y (2004) Development of Abeta terminal end-specific antibodies and sensitive ELISA for Abeta variant. Biochem Biophys Res Commun 319, 733-737.

[49] Kuo YM, Beach TG, Sue LI, Scott S, Layne KJ, Kokjohn TA, Kalback WM, Luehrs DC, Vishnivetskaya TA, Abramowski D, Sturchler-Pierrat C, Staufenbiel M, Weller RO, Roher AE (2001) The evolution of A beta peptide burden in the 
APP23 transgenic mice: implications for A beta deposition in Alzheimer disease. Mol Med 7, 609-618.

[50] Aoki M, Volkmann I, Tjernberg LO, Winblad B, Bogdanovic N (2008) Amyloid beta-peptide levels in laser capture microdissected cornu ammonis 1 pyramidal neurons of Alzheimer's brain. Neuroreport 19, 1085-1089.

[51] Kayed R, Head E, Sarsoza F, Saing T, Cotman CW, Necula M, Margol L, Wu J, Breydo L, Thompson JL, Rasool S, Gurlo T, Butler P, Glabe CG (2007) Fibril specific, conformation dependent antibodies recognize a generic epitope common to amyloid fibrils and fibrillar oligomers that is absent in prefibrillar oligomers. Mol Neurodegener 2, 18.

[52] Odom DT, Dowell RD, Jacobsen ES, Gordon W, Danford TW, MacIsaac KD, Rolfe PA, Conboy CM, Gifford DK, Fraenkel E (2007) Tissue-specific transcriptional regulation has diverged significantly between human and mouse. Nat Genet 39, 730732.

[53] Urdinguio RG, Sanchez-Mut JV, Esteller M (2009) Epigenetic mechanisms in neurological diseases: genes, syndromes, and therapies. Lancet Neurol 8, 1056-1072.

[54] Wegiel J (2002) Intraneuronal accumulation of N-terminally truncated amyloid beta. J Neuropathol Exp Neurol 61, 483483.

[55] Van Broeck B, Vanhoutte G, Pirici D, Van Dam D, Wils H, Cuijt I, Vennekens K, (2008), Theuns J, (2008) Intraneuronal amyloid $\beta$ and reduced brain volume in a novel APP T714I mouse model for Alzheimer's disease. Neurobiol Aging 2, 241-252.

[56] Kim KS, Wen GY, Bancher C, Chen CMJ, Sapienza VJ, Hong H, Wisniewski HM (1990) Detection and quantitation of amyloid beta peptide with two monoclonal antibodies. Neurosci Res Commun, 113-122.

[57] Wang R, Sweeney D, Gandy SE, Sisodia SS (1996) The profile of soluble amyloid beta protein in cultured cell media. Detection and quantification of amyloid beta protein and variants by immunoprecipitation-mass spectrometry. J Biol Chem 271, 31894-31902.

[58] 58. Matsunaga Y, Saito N, Fujii A, Yokotani J, Takakura T, Nishimura T, Esaki H, Yamada T (2002) A pH-dependent conformational transition of Abeta peptide and physicochemical properties of the conformers in the glial cell. Biochem J 361, $547-556$. 